\title{
FROM THE HISTORY OF TRANSFORMATION PROCESSES OF IRRIGATION SYSTEM IN THE FERGHANA VALLEY DURING INDEPENDENT PERIOD
}

\author{
Rakhmonov Golib Akhmadjonovich \\ Teacher at the chair of "Civil society" of Ferghana State University, Ferghana, Republic of \\ Uzbekistan
}

Article DOI: https://doi.org/10.36713/epra4268

\begin{abstract}
The article analyzes the history of transformation processes in the water management system of the Ferghana Valley during the years of independence, the provision of modern equipment and facilities, protection of water resources, reclamation of irrigated lands, reconstruction, repair of hydraulic structures and increasing capital investment made as well.
\end{abstract}

KEY WORDS: Ferghana Valley, irrigation, water shortage, land reclamation, modernization, transformation, credit, irrigation canal, reconstruction, hydraulic structures.

\section{INTRODUCTION}

As we know, during the years of independence, the issues of rational use and protection of water resources in the republic, as well as in the Ferghana Valley, have been focused on as one of the priorities of state policy. Because, agriculture is one of the most important sectors of the economy, most lands are based on irrigated agriculture and land reclamation. More decrees and resolutions adopted by the President of the Republic of Uzbekistan in order to develop the industry and increase its efficiency, as well as the work carried out on their basis, are a clear proof of our opinion. For example, it should be noted that the Address of the President of the Republic of Uzbekistan to the Oliy Majlis on January 24, 2020 includes a number of important areas, such as bringing water management to a new level, the widespread introduction of energysaving irrigation technologies in agriculture, automation of water resources control and accounting systems. tasks were assigned. In particular, the statement reads: "In 2020, we will introduce watersaving technologies on 44,000 hectares of land, or almost 4 times more than last year. For this purpose, 300 billion soums will be allocated from the state budget. It is also necessary to automate the management of water facilities, water control and accounting systems. These issues should be reflected in the concept of water management development. Let the Cabinet of Ministers submit the draft concept for approval by April 1 of this year"[1].

\section{RESEARCH METHODS}

Also, during the years of independence, some laws have been developed and implemented in order to develop the system and legally guarantee it in the country. Therefore, these legal documents are also aimed at protecting irrigation facilities in the Ferghana Valley. In particular, the Law "On Water and Water Use", adopted on May 6, 1993, is devoted to the rational use of water resources. In particular, Article 111 states: "The main and basin schedules for integrated water use and protection must be implemented to meet the future water needs of the population and the economy, as well as to protect water and prevent harmful effects of water. and other measures "[2.p.45]. It is obviously say that during the current reform process, a special program for the development of the country has been developed, which is the basis for the successful solution of socioeconomic problems, primarily to meet the needs and requirements of the next generation living in the country to maintain a balanced natural resources and environment creates. 


\section{SJIF Impact Factor: 6.260| ISI I.F.Value:1.241| Journal DOI: 10.36713/epra2016 ISSN: 2455-7838(Online) EPRA International Journal of Research and Development (IJRD)}

\section{RESULTS AND DISCUSSIONS}

We should give more examples oft this article. Besides, it should be noted that ensuring the legal effectiveness of the protection of water resources in many respects is the legal basis for this work, in particular, after the independence of Uzbekistan, this issue began to receive serious attention. In particular, great attention was paid to the creation of a legal framework for the protection of nature and water resources and the improvement of legislation in this area. Two direct articles of the Constitution of the Republic of Uzbekistan are devoted to this issue. For example, Article 50 of the Constitution states: "Citizens are obliged to treat the environment with care" [3.p.10] and Article 55 states: "Land, subsoil resources, water, flora and fauna and other natural resources are national wealth, they must be used wisely and they are under the protection of the state "[3.p.11]. Exactly in accordance with the Constitution, a number of laws and regulations have been developed. In particular, the laws "On water and water use" and "Nature protection" are directly aimed at the protection of nature and water resources. Therefore, the Law on Water and Water Use emphasizes the protection of water resources, and Chapter Nineteen directly addresses the use of water bodies for wastewater discharge, for example Article 73: "Permission to use water bodies for wastewater discharge In accordance with the legislation on the use of water bodies for the discharge of industrial, communal, sewage and other wastewater, as well as the state bodies of nature protection, water management sanitary control, the legislative bodies of the State Geology and Mineral Resources, agreed with the permission of the road can be build [2.p.39].

All fields are rising in the years which we investigate. During the years of independence in the Ferghana Valley, the development of irrigation and land reclamation and strengthening the financial support of the system has risen to the level of state policy. In particular, in accordance with the Resolution of the President of the Republic of Uzbekistan dated December 23, 2016 "On the Investment Program of the Republic of Uzbekistan for 2017" [4] in the system of the Ministry of Agriculture and Water Resources in 2017, 131.49 $\mathrm{mln}$. It is planned to use financial and credit funds in the amount of 198.77 million US dollars for these projects this year. Capital investments in the amount of USD (109.5\%) were directed and used. In particular, the expenditures for the development of the irrigation system consisted of the following stages. With the support of the World Bank, which has international powers and capabilities, the second phase of the project "Management of water resources in the Ferghana Valley" was implemented by the
President of the Republic on 16 September 2015. It is obvious that during the years of independence a number of important measures have been taken to modernize the irrigation system, to reconstruct irrigation facilities.

One of the special decrees is proclaimed in 2017. Also, President of Uzbekistan Sh. Mirziyoyev on September 16, 2017 "On the management of water resources in the Ferghana Valley". Resolution No. PP-3282 "On measures to implement the project. Phase 2 with the participation of the World Bank". On 30.06.2017, the Board of Directors of the World Bank approved a loan to Uzbekistan in the amount of 144.9 million US dollars for a period of 25 years with a grace period of 5 years [5]. At the same time, an EU grant of $\$ 16.4$ million is being used to provide additional funding for the project. The total cost of the project is 228.2 million US dollars, of which 83.3 million US dollars - the contribution of Uzbekistan (36.9 million US dollars - in the form of tax and customs benefits). The project will be implemented in Andijan, Namangan and Ferghana regions in 20172024. The Ministry of Agriculture and Water Resources has been appointed as the executive body responsible for project implementation, targeted and effective use of loans and achievement of all targets. Management and coordination of the project implementation is entrusted to the Center for Implementation of Investment Projects in Agriculture and Water Resources.

In 2018,35 water supply systems with a total length of $680 \mathrm{~km}$ were created under the project of the Swiss Cooperation Office "Water supply and sanitation in rural areas of Uzbekistan". Residents of Ferghana, Andizhan and Namangan regions have been provided with quality drinking water for 14 years. During this period, as a result of small-scale project activities, 160,000 people were provided with quality drinking water in 24 villages of Ferghana, Andizhan, Namangan and Syrdarya regions, and 687 $\mathrm{km}$ of water supply systems were built [6].

The draft State Program on the implementation of the Action Strategy for the five priority areas of development of the Republic of Uzbekistan in 2017-2021 in the "Year of Science, Enlightenment and Digital Economy" with the participation of the general public in order to consistently continue the comprehensive reforms in the interests of the people prepared with detailed discussion. In the course of the discussions, our people, civil society institutions were active, more than a thousand live conversations were organized with them on TV and radio channels, the proposals and recommendations of our citizens were analyzed in depth with the participation of relevant experts and expert groups. On this basis, the Cabinet of Ministers 


\section{SJIF Impact Factor: 6.260| ISI I.F.Value:1.241| Journal DOI: 10.36713/epra2016 ISSN: 2455-7838(Online) EPRA International Journal of Research and Development (IJRD) Volume: 5 | Issue: 4 | April 2020

and the Central Bank of the Republic of Uzbekistan were instructed to ensure the development of concepts for the development of water resources, a program of practical measures for the widespread introduction of digital technologies in agriculture. At the same time, the Cabinet of Ministers of the Republic of Uzbekistan together with the relevant ministries and departments was instructed to ensure the timely implementation of tasks in this area, including the development of draft laws "On water supply and sewerage services".

Among the ongoing reforms are to ensure the effectiveness of work in the field of water management in the Ferghana Valley, expand and strengthen international relations in the field of water management, timely and quality development of the concept of water management in 2020-2030, implementation of promising projects in the water sector. work on construction, reconstruction and modernization of water facilities by expanding the attraction of investments, loans and grants it is envisaged that the ahas will also be carried out gradually in the future.

\section{CONCLUSION}

In conclusion, significant work and important measures have been taken to modernize the irrigation system in the Ferghana Valley. In order to modernize the system, a large amount of capital was spent on it, and this figure has been growing from year to year. As a result, irrigation and land reclamation areas have been provided with modern equipment. During the years of independence, a number of practical measures have been taken to further improve the water supply of arable lands in the valley, the efficient use of land and water resources, the development of the sector, increasing the productivity of agricultural crops.

\section{REFERENCES}

1. Address of the President of the Republic of Uzbekistan Shavkat Mirziyoyev to the Oliy Majlis. January 24, 2020. www.prezident.uz.

2. Collection of the legislation of the Republic of Uzbekistan.-Tashkent: Adolat, 2009. -№52, Article 555.-P.34-51.

3. The Constitution of the Republic of Uzbekistan.Tashkent: Uzbekistan, 2019.

4. http://agro.uz./uz/information.about.agriculture.

1. 5.https://www.norma.uz/qonunchilikda_yangi/far gona_vodiysining_suv_taminotiga_2282_mln_dol lar_investiciya_qilinadi

5. https://daryo.uz/k/2018/04/25/fargonavodiysidagi-uylarga-qay-tarzda-suv-keldi/ 